\title{
Effect of Intraspecific Competition and Substrate Type on Terpene Emissions from Some Mediterranean Plant Species
}

\author{
Elena Ormeño • Anne Bousquet-Mélou • Jean-Philippe Mévy • Stéphane Greff • \\ Christine Robles • Gilles Bonin • Catherine Fernandez
}

\begin{abstract}
Competition is an important factor that has been extensively reported in the Mediterranean area. There is evidence that leaf terpene accumulation may vary between plants growing on calcareous and siliceous soils. In the present study, leaf terpene emissions from potted seedlings of Pinus halepensis, Cistus albidus, and Quercus coccifera, growing under natural environmental conditions on calcareous and siliceous substrates, were studied by using a bag enclosure method. In both substrates, seedlings were potted alone and in intraspecific competition, to examine the effect of substrate type and that of intraspecific competition on terpene emissions. The results showed that competition favored: (i) overall monoterpene and sesquiterpene emissions from $Q$. coccifera; (ii) overall monoterpene emissions from P. halepensis; (iii) overall sesquiterpene emissions from $C$. albidus. Substrate type affected terpene emissions to a limited extent and in a species-specific way. Whereas for $Q$. coccifera, the overall monoterpene emissions and that of Allo-aromadendrene were favored on siliceous substrate, no significant changes were found in emissions from $P$. halepensis. Only the release of AR-curcumene from $C$. albidus was higher on siliceous substrate. We also found high variability in terpene emission composition from the study species, particularly for $P$. halepensis and $Q$. coccifera. These two species released both monoterpenes and sesquiterpenes, instead of monoterpenes only, as shown in previous studies.
\end{abstract}

Keywords Plant interaction - Soil nutrient availability · Biotic stress factors · BVOC . Sesquiterpenes $\cdot$ Monoterpenes $\cdot$ Secondary metabolism

\section{Introduction}

Emission of biogenic volatile organic compounds (BVOC) from leaves is an important mechanism through which plants modify air quality on a global (Guenther et al., 1995), regional

E. Ormeño $(\varangle) \cdot$ A. Bousquet-Mélou $\cdot$ J.-P. Mévy $•$ S. Greff $•$ C. Robles $\cdot$ G. Bonin $\cdot$ C. Fernandez Institut Méditerranéen d'Ecologie et Paléoécologie (IMEP) - UMR CNRS 6116,

Equipe Ecologie Fonctionnelle, Université de Provence Centre de St Jérôme,

Case 421 Avenue Escadrille Normandie Niémen. 13397, Marseille, France

e-mail: elena.ormeno@univ-cezanne.fr 
(Fuentes et al., 2000), and local scale (Simon et al., 2001). In particular, oxidation of terpenes contributes to both ozone $\left(\mathrm{O}_{3}\right)$ and secondary organic aerosols (Guenther, 2002). In addition, these natural emissions may increase the life span of greenhouse gases, such as $\mathrm{CH}_{4}$, which are related to the pattern of global climatic change (Guenther et al., 1995). Consequently, there is interest in understanding which environmental factors affect terpene emissions from plants. This especially concerns Mediterranean regions, as such emissions are directly implicated in $\mathrm{O}_{3}$ concentration even on a local scale (Simon et al., 2005), and this secondary pollutant exceeds the European tolerated limits several times per year (Millan et al., 1996). Although the scientific community has devoted considerable effort to understand the effect of environmental factors on BVOC in the Mediterranean Region, estimates of these compounds are still uncertain (Staudt et al., 2000). This is partly because of the range of factors controlling these emissions.

With regard to abiotic factors, few studies have addressed the issue of soil nutrient effects on terpene emissions, whereas the effect of climate-related factors is well documented. In contrast to released terpenes, studies dealing with soil nutrient effects on stored or accumulated terpenes within leaves have been more frequent (e.g., Kainulainen et al., 1996; Close et al., 2004). However, those studies were performed on the basis of different fertilizer treatments (Harley et al., 1994; Litvak et al., 1996), and they show inconsistent results. Only a few studies have shown that plant emissions vary on soils of different natural fertility, such as calcareous and siliceous soils. Robles and Garzino, (1998) and Flamini et al. (2004) showed that some terpene content from Mediterranean species varied according to soil type. However, other studies have shown that there is no correlation between terpene content and emissions (Gershenzon et al., 2000). The degree of dependency of terpene emissions on soil type will not necessarily be the same as that found for terpenes stored within leaves.

With regard to biotic interference on emissions, terpenes are currently associated with: (i) attractant compounds that favor pollination or seed dispersal (Caissard et al., 2004); (ii) herbivore and pathogen deterrents (Holopainen, 2004); and (iii) plant to plant communication (Gniazdowska and Bogatek, 2005).

Plant to plant competition is common under natural conditions (Goldberg and Barton, 1992), and one prevalent interaction is competition for limited resources. As soils are often nutrient-poor in Mediterranean regions, the study of competition is of particular interest. Moreover, plant biomass and growth are especially sensitive to competition (Ramseier and Weiner, 2006; Midoko-Iponga et al., 2005), and these factors may explain some BVOC variability among plants of the same species (Batten et al., 1995). Nevertheless, the effect of this factor remains almost wholly unexplored, as only a single study is available on terpene emission response to competition (Peñuelas and Llusià, 1998).

The aim of this work was to examine whether terpene emissions change when plants grow: (i) on calcareous or siliceous substrate, and (ii) alone or in intraspecific competition. We also analyzed whether these two factors interact, as it has been reported that competition for nutrients is more intensive when nutrient availability is high (Vila and Sardans, 1999).

\section{Methods and Materials}

Species Studied Terpene emissions from Pinus halepensis Mill. (Pinales, Pinaceae), Cistus albidus L. (Malvales, Cistaceae), and Quercus coccifera L. (Fagales, Fagaceae), which are typical of the Mediterranean area, were studied. The tree species studied, P. halepensis, is representative throughout the Mediterranean Basin, where it is widespread (Quézel, 2000). P. halepensis (Orshan, 1989) and C. albidus (Passama, 1970) grow both on calcareous and siliceous substrates even if they are mainly calcicole species. Q. coccifera is rarely found on 
siliceous soils (Bornand et al., 1997). All study species form both monospecific and mixed stands in Mediterranean ecosystems. However, they often form dense and abundant monospecific stands in areas that have been previously disturbed by recurrent fire ( $Q$. coccifera, Larcheveque et al., 2005; C. albidus, Robles, 1998; P. halepensis, Barbero et al., 1990).

Experimental Setup The study was performed on 2-yr-old potted seedlings. Seedlings were obtained from plant collections of the nursery garden (Luberon, Lambesc, southern France). For each species, four seedlings were potted alone (four pots, four seedlings) and four other seedlings were potted with another seedling of the same species (in intraspecific conditions) (four pots, four seedlings). In both cases, seedlings were potted on siliceous and on calcareous substrates, thus making a total of 16 seedlings per species. All seedlings were irrigated similarly and regularly to avoid any water stress. Substrates came from natural garrigue sites (of southern France) from the first $25 \mathrm{~cm}$ of the soil layer. Soils were sampled in May 2003 and then potting took place over several weeks in summer 2003.

The main physical and chemical properties of calcareous and siliceous substrates were analyzed (Table 1). Calcareous substrate was mainly characterized by higher values of $\mathrm{N}$, $\mathrm{Ca}^{2+}$, TOC (total organic carbon), $\mathrm{K}^{+}, \mathrm{pH}$, clay, and silt (Table 1), whereas siliceous substrate showed mainly higher values of $\mathrm{Mg}^{2+}$ and sand.

Terpene emission sampling was performed from 15-19 April 2004, from 11:00 to 15:30 (solar time). Experimentation was carried out under natural environmental conditions. During the study period, air temperature varied between 23 and $27^{\circ} \mathrm{C}$, PAR (Photosynthetically Active Radiation) ranged from 800 to $1,000 \mu \mathrm{mol} \mathrm{m} \mathrm{m}^{-2}$, wind speed was negligible, and air humidity was less than $30 \%$. Weather was typical of the spring season, with alternative cloudy and sunny sky.

Terpene Sampling A semidynamic bag enclosure system, made of Teflon film (FEP), was applied to enclose a single healthy twig per plant. The health of leaves was visually checked. Sun- and shade-exposed leaves, as well as primary and secondary leaves, were considered. The emission rate obtained through this method may be taken as a representation of the mean emission rate. The system consisted of 16 bag enclosures. Each (0.5 1) was designed with two air streams, inlet and outlet.

Table 1 Physical and chemical properties of the calcareous and siliceous substrates studied

\begin{tabular}{|c|c|c|}
\hline Properties & Siliceous Substrate & Calcareous Substrate \\
\hline $\mathrm{pH}\left(\mathrm{H}_{2} \mathrm{O}\right)$ & $6.18 \pm 0.20$ & $7.22 \pm 0.09$ \\
\hline TOC (total organic C) (\%) & $1.80 \pm 0.28$ & $5.96 \pm 0.35$ \\
\hline Total N (\%) & $0.084 \pm 0.005$ & $0.334 \pm 0.005$ \\
\hline $\mathrm{C} / \mathrm{N}$ & $20.87 \pm 2.05$ & $17.75 \pm 0.86$ \\
\hline Available P (mg.kg $\left.{ }^{-1}\right)$ (Olsen) & $36.14 \pm 4.24$ & $32.43 \pm 1.12$ \\
\hline Total P (mg.kg $\left.{ }^{-1}\right)$ & $277.28 \pm 34.83$ & $724.57 \pm 38.15$ \\
\hline $\mathrm{K}^{+}\left(\mathrm{mg} \cdot \mathrm{kg}^{-1}\right)$ & $190.60 \pm 20.66$ & $501.70 \pm 43.08$ \\
\hline $\mathrm{Ca}^{2+}\left(\mathrm{mg} \cdot \mathrm{kg}^{-1}\right)$ & $2052.71 \pm 156.47$ & $9768.20 \pm 319.81$ \\
\hline $\mathrm{Mg}^{2+}\left(\mathrm{mg} \cdot \mathrm{kg}^{-1}\right)$ & $127.78 \pm 9.43$ & $102.44 \pm 46.12$ \\
\hline Sand ( $\%$ of fine and coarse earth) & $74.72 \pm 1.91$ & $28.06 \pm 3.61$ \\
\hline Silt (\% of fine and coarse earth) & $15.71 \pm 3.02$ & $30.56 \pm 4.30$ \\
\hline Clay (\% of fine and coarse earth) & $10.1 \pm 1.77$ & $22.95 \pm 3.21$ \\
\hline Texture (Aubert, 1978) & Sandy loam & loam \\
\hline
\end{tabular}

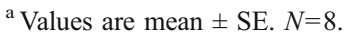


Before samples were taken, the bag air was renewed, and each bag was continuously flushed with nonpolluted air (Alphagaz, 99.99\% purity, Type 1) through a Tygon tube (Tygon ${ }^{\circledR}$ Fuel and lubricant tubing; o.d: $11.2 \mathrm{~mm}$, i.d: $8 \mathrm{~mm}$ ), especially designed for hydrocarbon transport. Inflowing air (Qe) was measured with a digital mass-flow controller (Aalborg ${ }^{\circledR}$ CFC17, 0-500 ml). Qe was $110 \pm 20 \mathrm{ml} \mathrm{min}^{-1}$ and was maintained for $15 \mathrm{~min}$, so that the bag air was renewed three times. After air renewal, terpene sampling took place (while inflowing air was maintained). The outgoing terpenes from each bag enclosure were collected on glass sorbent tubes filled with preconditioned Tenax TA (Varian ${ }^{2}$ : 20-35 mesh, $150 \mathrm{mg}, 160 \times 5 \times 3 \mathrm{~mm})$, using a pumping system $\left(\right.$ Edwards $\left.{ }^{\circledR}\right)$ placed downstream of the Tenax TA. One sorbent tube per bag was used. We previously demonstrated in the laboratory that there were no significant differences between trapped terpene concentrations in four Tenax TA placed simultaneously at different air stream outlets of the same bag enclosure. Outflowing air (Qs) at each bag enclosure was measured with a bubble flow meter (0-280 ml/min, GPE Meterate 314-140/084), placed immediately after each sorbent tube. Flow meters were specially designed to allow connection to a tube, as each bubble flow meter was linked to the pump by means of a reinforced flexible antioxidant PVC tube (i.d. $0.8 \mathrm{~mm}$ ). Terpene sampling took place for $10 \mathrm{~min}$ at $\mathrm{Qs}=80 \pm 30 \mathrm{ml} \mathrm{min}{ }^{-1}$. Constancy of Qs at each bag enclosure was verified every $2 \mathrm{~min}$. Of the 16 bag enclosures constructed, only 14 were directly used to sample terpene emissions; one was always allocated to a blank with no twig in the gas exchange system, and another was used for measurements of air temperature inside the enclosure. After measurements, each sampled twig was cut off and stored in a portable refrigerator at $+4^{\circ} \mathrm{C}$ until being stored at $-20^{\circ} \mathrm{C}$ in the laboratory. Leaves from each twig were separated and lyophilized to measure dry mass (DM).

Terpene Analyses Adsorbed terpenes in Tenax TA were analyzed through thermal desorption by gas chromatography (GC) fitted with a Flame ionization detector (FID) $\left(H P{ }^{\circledR} 5890\right.$ series II). Before thermal desorption, a preflush phase was run $(3 \mathrm{~min}, 10 \mathrm{ml}$ $\min ^{-1}, 60^{\circ} \mathrm{C}$ ), to allow humidity in Tenax TA to be evacuated. This phase was also necessary to accurately analyze sesquiterpene adsorbed compounds. Then, thermal desorption (Thermal Desorption Cold Trap injector, Varian ${ }^{\circledR}$, CP4020-TCT model) was

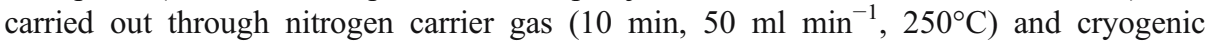
concentration in a silica capillary trap, cooled with liquid nitrogen at $-100^{\circ} \mathrm{C}$. Finally, compounds were separated in the nonpolar chromatographic column (Ultra 2, $50 \mathrm{~m} \times$ $0.2 \mathrm{~mm} \times 0.25 \mu \mathrm{m})$.

The identity of terpenes was confirmed by comparison with standards of high purity (Aldrich-Firminich). Calibration of monoterpene and sesquiterpene factor response, used to calculate their concentrations, was performed periodically throughout the sampling period. In a few cases, when standards were not available, peak identification was achieved by injection of previously extracted terpenes from each species, in Tenax TA. The identity of these compounds was determined by means of a GC (HP®6890) coupled with a mass spectrometer (MS) (HP®5973 Network Mass Selective Detector).

Statistical Analyses and Standard Terpene Emission Calculation Statistical treatments were applied to standardized emissions. In the case of $P$. halepensis and $C$. albidus, standardization at $30^{\circ} \mathrm{C}$ was carried out with the algorithm proposed by Tingey et al. (1980), as temperature is considered to be the main factor controlling emissions from these storing species in the short-term (Llusià and Peñuelas, 2000). As Q. coccifera is a nonstoring species, emissions were standardized at $30^{\circ} \mathrm{C}$ and $1,000 \mu \mathrm{mol} \mathrm{s} \mathrm{m}^{-2}$ according to the model of Guenther et al. (1995). Temperature and light are currently agreed to be the 
main factors controlling monoterpene emissions from nonstoring species (Staudt et al., 2000). Thus, all emission data presented throughout this study represent standard emissions, expressed as mean $\pm \mathrm{SE}$.

Two-factor analysis of variance (ANOVAs) was applied to test the effect of both substrate type and intraspecific competition, and possible interacting effects between factors. This statistical test was performed for the overall monoterpene and sesquiterpene emissions, and for the major compounds released from each species. Data were logtransformed, when necessary, to meet normal requirements for ANOVAs analysis. Statistical analyses were performed by using Statistical Graphics ${ }^{\circledR}$ version 4.1 .

\section{Results}

P. halepensis mainly emits monoterpenes (Table 2). Overall monoterpene emission rate is $3.12 \pm 0.75 \mu \mathrm{g} \mathrm{h}^{-1} \mathrm{~g}_{\mathrm{DM}}{ }^{-1}$, whereas that of sesquiterpenes is only $0.29 \pm 0.04 \mu \mathrm{g} \mathrm{h}^{-1} \mathrm{~g}_{\mathrm{DM}}{ }^{-1}$.

Table 2 Terpene emission composition from leaves of P. halepensis, C. albidus, and $Q$. coccifera

\begin{tabular}{|c|c|c|c|c|c|}
\hline Monoterpenes & P. halepensis & C. albidus & Q. coccifera & CAS Number & RI \\
\hline$\alpha$-thujene & tc & & - & $2867-05-2$ & 919 \\
\hline$\alpha$-pinene & $X$ & $X$ & $X$ & $80-56-8$ & 926 \\
\hline Camphene & $X$ & 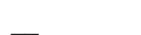 & 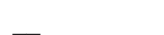 & $79-92-5$ & 944 \\
\hline sabinene & $\mathrm{X}$ & $\bar{X}$ & $\bar{X}$ & $3387-41-5$ & 960 \\
\hline$\beta$-pinene & $\mathrm{X}$ & $\mathrm{X}$ & $\mathrm{X}$ & $127-91-3$ & 965 \\
\hline$\beta$-myrcene & $\mathrm{X}$ & $\mathrm{X}$ & tc & $123-35-3$ & 969 \\
\hline$\Delta^{3}$-carene & $\mathrm{X}$ & tc & tc & $13466-78-9$ & 1010 \\
\hline$\alpha$-terpinene & tc & - & - & $99-86-5$ & 1015 \\
\hline p-cymene & $\mathrm{X}$ & - & - & $99-87-6$ & 1032 \\
\hline$\Delta$-limonene & $\mathrm{X}$ & $\overline{\text { tc }}$ & - & $138-86-3$ & 1035 \\
\hline$\beta$-ocimene & tc & - & - & $13877-91-3$ & 1040 \\
\hline$\gamma$-terpinene & $\mathrm{X}$ & - & - & $99-85-4$ & 1060 \\
\hline$\Delta$-terpinene & $\mathrm{X}$ & $\overline{\text { tc }}$ & $\bar{X}$ & $586-62-9$ & 1090 \\
\hline Linalool & $\mathrm{X}$ & $\mathrm{X}$ & $\mathrm{X}$ & $78-70-6$ & 1100 \\
\hline Camphor & tc & - & - & $76-22-2$ & 1159 \\
\hline Borneol & $\mathrm{X}$ & $\overline{\text { tc }}$ & $\overline{\mathrm{tc}}$ & $507-70-0$ & 1179 \\
\hline$\alpha$-terpineol & $\mathrm{X}$ & tc & tc & $98-55-5$ & 1203 \\
\hline \multicolumn{6}{|l|}{ Sesquiterpenes } \\
\hline Copaene & tc & $\mathrm{X}$ & $\mathrm{X}$ & $3856-25-5$ & 1378 \\
\hline$\beta$-bourbonene & $\mathrm{X}$ & $\mathrm{X}$ & - & $5208-59-3$ & 1402 \\
\hline$\beta$-caryophyllene & $\mathrm{X}$ & $\mathrm{X}$ & - & $87-44-5$ & 1444 \\
\hline Unknonwn $(m / z=204)$ & $\mathrm{X}$ & $\mathrm{X}$ & $\bar{X}$ & $24406-05-1$ & 1473 \\
\hline$\alpha$-caryophyllene & $\mathrm{X}$ & $\mathrm{X}$ & $\mathrm{X}$ & $6753-98-6$ & 1478 \\
\hline Allo-aromadendrene & $\mathrm{X}$ & $\mathrm{X}$ & $X$ & $25246-27-9$ & 1485 \\
\hline AR-curcumene & - & $\mathrm{X}$ & tc & $644-30-4$ & 1489 \\
\hline$\alpha$-zingiberene & $\bar{X}$ & $\mathrm{X}$ & - & $495-60-3$ & 1499 \\
\hline$\alpha$-muurolene & $\mathrm{X}$ & $\mathrm{X}$ & $\bar{X}$ & $10208-80-7$ & 1516 \\
\hline$\gamma$-cadinene & _- & $\mathrm{X}$ & - & $39029-41-9$ & 1519 \\
\hline$\Delta$-cadinene & - & tc & - & $483-76-1$ & 1523 \\
\hline
\end{tabular}

\footnotetext{
${ }^{\mathrm{a}} \mathrm{X}$ : detected compound

b_ _ : not detected compound

${ }^{\mathrm{c}}$ tc: compound detected in trace amounts

${ }^{\mathrm{d}} \mathrm{RI}$ : retention index
} 
The major released compounds are $\alpha$-pinene and $\Delta^{3}$-carene. Substrate type does not significantly modify either the overall monoterpene and sesquiterpene emissions (ANOVAs, $P>0.05$; Fig. 1) or those of any major compound (ANOVAs, $P>0.05$; Table 3 ). Whereas substrate type has no effect on terpene emissions from $P$. halepensis, its overall monoterpene emissions (ANOVAs, $P<0.05$; Fig. 1) and emissions of all major monoterpenes, except those of $\beta$-pinene (ANOVAs, $P>0.05$; Table 3 ), increase significantly in conditions of intraspecific competition, irrespective of substrate type. By contrast, the overall sesquiterpene emissions do not change in competition (ANOVAs, $P>0.05$; Fig. 1)

C. albidus is mainly a sesquiterpene emitter (Table 2). Sesquiterpene emission rate is about threefold that of monoterpenes $\left(4.44 \pm 1.08 \mu \mathrm{g} \mathrm{h}^{-1} \mathrm{~g}_{\mathrm{DM}}{ }^{-1}\right)$. The major sesquiterpenes emitted are $\alpha$-zingiberene, followed by AR-curcumene and allo-aromadendrene (Table 3). Among the monoterpenes, only $\alpha$-pinene shows high emission rates. Neither the overall monoterpene, nor the overall sesquiterpene emission rates, show significant changes on calcareous and siliceous substrates (ANOVAs, $P>0.05$; Fig. 1). Only emissions of ARcurcumene rise when seedlings of $C$. albidus grow on siliceous substrate (ANOVAs, $P<$ 0.05; Table 3). By contrast, emissions from $C$. albidus are markedly dependent on competition, irrespective of substrate type. The overall sesquiterpene emissions (Fig. 1), and those of $\beta$-bourbonene and $\beta$-caryophyllene, are significantly higher when this species grows in competition (ANOVAs, $P<0.05$; Table 3).

Finally, $Q$. coccifera releases monoterpenes and sesquiterpenes similarly (Table 2). This species shows the lowest emission rate of species examined here (Fig. 1). The major monoterpenes released are $\alpha$-pinene, followed by $\beta$-pinene and sabinene (Table 3 ). The major sesquiterpenes released are $\alpha$-caryophyllene and allo-aromadendrene (Table 3). Emission of the overall monoterpenes is significantly higher when $Q$. coccifera grows on siliceous substrate $(A N O V A s, P<0.05$; Fig. 1). This is caused by $\alpha$-pinene, which is the only major monoterpene emitted in higher amounts when seedlings grow on siliceous

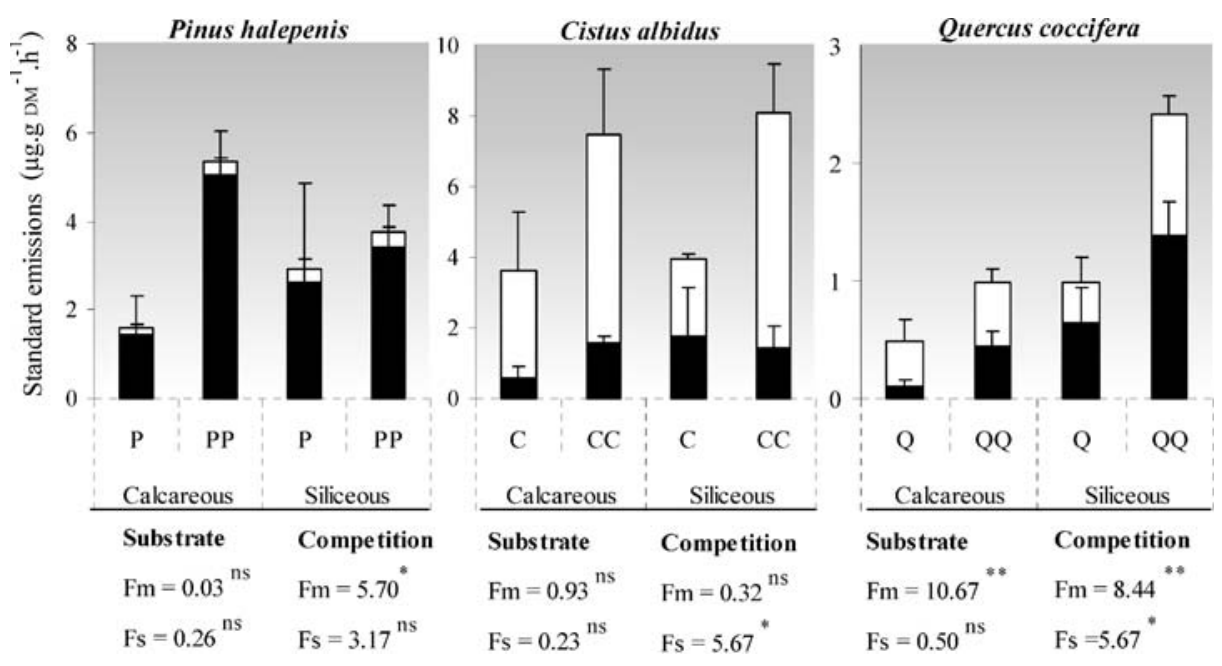

Fig. 1 Monoterpene and sesquiterpene standard emissions from P. halepensis, C. albidus, and Q. coccifera on calcareous and siliceous substrates, isolated and in intraspecific competition. Values are mean $\pm \operatorname{SE}(N=$ 4). Bars indicate the standard error. P, C, Q: isolated seedlings. PP, CC, QQ: seedlings in intraspecific competition. Results of the two-way ANOVAs (substrate and competition) are also shown. $F m$, $F s$ : test values for monoterpenes and sesquiterpenes, respectively; ns: not significant at $95 \%$ of confidence; $* 0.01<P$ $<0.05 ; * * 0.001<P<0.01$ 
Table 3 Mean standard emission of each major compound released by leaves of $P$. halepensis, C. albidus, and $Q$. coccifera on calcareous and siliceous substrates, isolated and in intraspecific competition

\begin{tabular}{|c|c|c|c|c|c|c|}
\hline P. halepensis & $\begin{array}{l}\text { Calcareous } \\
\text { Substrate }\end{array}$ & $\begin{array}{l}\text { Siliceous } \\
\text { SUbstrate }\end{array}$ & $F_{\text {substrate }}$ & Isolated & Competition & $F_{\text {competition }}$ \\
\hline$\alpha$-pinene & $1.47 \pm 0.39$ & $0.88 \pm 0.19$ & $1.65^{\mathrm{ns}}$ & $0.65 \pm 0.32$ & $1.41 \pm 0.28$ & $4.80 *$ \\
\hline$\beta$-pinene & $0.14 \pm 0.02$ & $0.24 \pm 0.11$ & $0.03^{\mathrm{ns}}$ & $0.12 \pm 0.03$ & $0.22 \pm 0.08$ & $1.17^{\mathrm{ns}}$ \\
\hline$\beta$-myrcene & $0.67 \pm 0.29$ & $0.43 \pm 0.17$ & $0.40^{\mathrm{ns}}$ & $0.14 \pm 0.04$ & $0.72 \pm 0.23$ & $7.10^{*}$ \\
\hline$\Delta^{3}$-carene & $0.75 \pm 0.18$ & $1.22 \pm 0.33$ & $0.60^{\mathrm{ns}}$ & $0.54 \pm 0.24$ & $1.14 \pm 0.23$ & $5.59^{*}$ \\
\hline \multicolumn{7}{|l|}{ C. albidus } \\
\hline$\alpha$-pinene & $0.27 \pm 0.11$ & $0.48 \pm 0.31$ & $1.48^{\mathrm{ns}}$ & $0.10 \pm 0.04$ & $0.52 \pm 0.28$ & $0.02^{\mathrm{ns}}$ \\
\hline$\beta$-bourbonene & $0.28 \pm 0.09$ & $0.47 \pm 0.12$ & $6.70^{\mathrm{ns}}$ & $0.24 \pm 0.08$ & $0.46 \pm 0.11$ & $4.96^{*}$ \\
\hline$\beta$-caryophyllene & $0.42 \pm 0.20$ & $0.45 \pm 0.30$ & $0.03^{\mathrm{ns}}$ & $0.06 \pm 0.02$ & $0.62 \pm 0.27$ & $5.32 *$ \\
\hline allo-aromadendrene & $0.69 \pm 0.21$ & $0.82 \pm 0.18$ & $0.01^{\mathrm{ns}}$ & $0.48 \pm 0.09$ & $0.91 \pm 0.19$ & $0.03^{\mathrm{ns}}$ \\
\hline AR-curcumene & $0.85 \pm 0.31$ & $1.02 \pm 0.23$ & $6.03 *$ & $0.64 \pm 0.35$ & $1.08 \pm 0.22$ & $0.51^{\mathrm{ns}}$ \\
\hline$\alpha$-zingiberene & $1.27 \pm 0.52$ & $1.14 \pm 0.38$ & $0.06^{\mathrm{ns}}$ & $0.74 \pm 0.33$ & $1.43 \pm 0.43$ & $0.08^{\mathrm{ns}}$ \\
\hline$\alpha$-muurolene & $0.32 \pm 0.05$ & $0.64 \pm 0.33$ & $0.39^{\mathrm{ns}}$ & $0.29 \pm 0.07$ & $0.59 \pm 0.26$ & $0.01^{\mathrm{ns}}$ \\
\hline \multicolumn{7}{|l|}{ Q. coccifera } \\
\hline$\alpha$-pinene & $0.10 \pm 0.04$ & $0.45 \pm 0.30$ & $11.53 * *$ & $0.20 \pm 0.10$ & $0.34 \pm 0.10$ & $7.21 *$ \\
\hline sabinene & $0.05 \pm 0.03$ & $0.11 \pm 0.32$ & $0.45^{\mathrm{ns}}$ & $0.04 \pm 0.02$ & $0.10 \pm 0.04$ & $4.78^{*}$ \\
\hline$\beta$-pinene & $0.09 \pm 0.07$ & $0.07 \pm 0.32$ & $0.02^{\mathrm{ns}}$ & $0.03 \pm 0.02$ & $0.10 \pm 0.05$ & $0.01^{\mathrm{ns}}$ \\
\hline$\alpha$-caryophyllene & $0.11 \pm 0.02$ & $0.17 \pm 0.04$ & $4.60 *$ & $0.06 \pm 0.03$ & $0.17 \pm 0.03$ & $9.83 * *$ \\
\hline allo-aromadendrene & $0.13 \pm 0.03$ & $0.26 \pm 0.06$ & $0.02^{\mathrm{ns}}$ & $0.05 \pm 0.03$ & $0.14 \pm 0.02$ & $6.21 *$ \\
\hline
\end{tabular}

${ }^{\mathrm{a}}$ The effects of substrate type and intraspecific competition on standard emissions of these compounds are tested through two-factor ANOVAs. $F_{\text {substrate }}$ and $F_{\text {competition }}$ indicate the ANOVA's value for each factor.

Values are mean $(n=4) \pm \mathrm{SE}$

$* 0.01<P<0.05$

** $0.001<P<0.01$

$\mathrm{ns}=$ not significant $(P>0.05)$

substrate (ANOVAs, $P<0.05$; Table 3). The overall sesquiterpene emissions do not significantly change according to substrate type (ANOVAs, $P>0.05$; Fig. 1). Only emissions of $\alpha$-caryophyllene are higher when seedlings are potted on siliceous substrate (ANOVAs, $P<0.05$; Fig. 1). With regard to competition, the overall monoterpene and sesquiterpene emissions are higher when $Q$. coccifera grows in intraspecific competition (ANOVAs, $P<$ 0.05; Fig. 1), both on calcareous and siliceous soils. Emissions of all major compounds, except those of $\beta$-pinene, are also higher in competition (ANOVAs, $P<0.05$; Table 3).

\section{Discussion}

The aim of the investigation was to extend our understanding of the dependency of terpene emissions on environmental factors. The effect of both substrate type and intraspecific competition, and their potential interaction, were explored on emissions from seedling plants. Despite the recognized importance of competition for different aspects of plant development (e.g., biomass, growth, phenology), little attention has been paid to the impact this biotic factor may have on terpene emissions. The results showed that even if calcareous and siliceous substrates differed in their nutrient resources, competition had a positive effect on terpene emissions among all species irrespective of the substrate type. Thus, this biotic factor had a positive effect on terpene emissions from $P$. halepensis (monoterpenes), C. albidus 
(sesquiterpenes), and Q. coccifera (monoterpenes and sesquiterpenes). Only Peñuelas and Llusià (1998) have previously dealt with the effect of competition on terpene emissions. These authors found similar results to those reported here. They observed that when two seedlings of $P$. halepensis grew together, monoterpene emissions were favored. However, they reported the opposite response for $Q$. ilex where seedlings growing alone showed higher emission rates. Hence, the pattern shown here for Q. coccifera in intraspecific competition is different from that reported for $Q$. ilex. Both Quercus are long-lived, perennial, and angiosperm species, with a broad edaphic tolerance. Moreover, their emissions have been shown to vary similarly with light and temperature (Niinemets et al., 2002). A possible explanation for the apparent difference in impact of intraspecific competition on terpene emissions between $Q$. ilex and $Q$. coccifera is that Peñuelas and Llusià (1998) added nutrients to substrates during the sampling period, whereas nutrients were not added in our study.

This is the first investigation into plant emissions on calcareous and siliceous substrates, and it shows that, in contrast to intraspecific competition, substrate type affects terpene emissions in a species-specific way. On one hand, monoterpene emissions from $Q$. coccifera were considerably higher on siliceous substrate. On the other, emissions from $P$. halepensis showed similar rates on calcareous and siliceous substrates. Finally, a single major compound released by $C$. albidus showed higher emission rates on siliceous substrate. We think that the higher terpene emissions reported in this study for $Q$. coccifera on siliceous soils is the consequence of stress, as this is a calcicole species that is rarely found on siliceous soils (Bornand et al., 1997).

This study also showed that sesquiterpenes have been neglected, in particular with regard to emissions from $Q$. coccifera, although they may constitute an important fraction of total emitted compounds. The lack of sesquiterpene emission data in previous studies for $Q$. coccifera and $P$. halepensis might, however, be explained by differences in sampling methodology and analysis protocols. Moreover, as sesquiterpenes may alter the tropospheric balance, notably by favoring aerosol formation (Guenther, 2002), their isoprenoids should not be excluded either from terpene emission inventories or from models designed for predicting secondary pollutant concentrations and climate change.

In summary, this study was carried out to contribute to a better understanding of environmental factors that modify the release of terpenes by plants. The results presented could be taken into account: (i) to update terpene emissions from these species in current terpene emission inventories, as sesquiterpenes have not so far been considered; (ii) as input in models commonly used for predicting terpene emissions from plants to obtain more accurate estimations; (iii) to obtain better insight into factors that modify the secondary metabolism of plants. In a broader perspective, it might be of interest to examine whether terpene emissions from these and other Mediterranean species show the same response to the factors analyzed here over the whole seasonal cycle.

Acknowledgments This research was primarily funded by the French Agriculture Minister (DERF), the Environmental agency (ADEME), and PACA region (Presence-Alpes-Côte d'Azur). We thank Sylvie Dupouyet for collaboration in measurement campaigns. We are grateful to Christine Ballini for advice on soil analysis. We are also grateful to Patrice Brahic, the director of the national nursery garden "Aix Les Milles," and Michael Paul for improvements in the English.

\section{References}

Aubert, G. 1978. Méthodes D'analyse Des Sols. Centre National de Documentation Pédagogique. Paris. BARbero, M., Bonin, G., LoISEL, R., and Quezel, P. 1990. Changes and disturbances of forest ecosystems caused by human activities in the western part of the Mediterranean Basin. Vegetatio 87:151-173. 
Batten, J. H., Stutte, G. W., and WheEleR, R. M. 1995. Effect of crop development on biogenic emissions from plant-populations grown in closed plant-growth chambers. Phytochemistry 39:1351-1357.

Bornand, M., Robbez-Masson, J. M., Donnet, A., and Lacaze, B. 1997. Caractérisation des sols et paysages des garrigues méditerranéennes. Etude et Gestion des sols 4:27-42.

Caissard, J. C., MeekiJjironenroj, A., Baudino, S., and Anstett, M. C. 2004. Localization of production and emission of pollinator attractant on whole leaves of Chamaerops humilis (Arecaceae). Am. J. Bot. 91:1190-1199.

Close, D. C., Mcarthur, C., Pietrzykowski, E., Fitzgerald, H., and Paterson, S. 2004. Evaluating effects of nursery and post-planting nutrient regimes on leaf chemistry and browsing of eucalypt seedlings in plantations. Forest Ecol. Manag. 200:101-112.

Flamini, G., Cioni, P. L., Morelli, I., Maccioni, S., and BAldini, R. 2004. Phytochemical typologies in some populations of Myrtus communis L. on caprione promontory (East Liguria, Italy). Food Chem. 85:599-604.

Fuentes, J. D., Lerdau, M., Atkinson, R., Baldocchi, D., Bottenheim, J. W., Ciccioli, P., Lamb, B., Geron, C., Gu, L., Guenther, A., Sharkey, T. D., and Stockwell, W. 2000. Biogenic hydrocarbons in the atmospheric boundary layer: A review. B. Am. Meteorol. Soc. 81:1537-1575.

Gershenzon, J., McConKey, M. E., and CroteAu, R. B. 2000. Regulation of monoterpene accumulation in leaves of peppermint. Plant Physiol. 122:205-213.

Gniazdowska, A. and BogateK, R. 2005. Allelopathic interactions between plants. Multi site action of allelochemicals. Acta Physiol. Plant 27:395-407.

GoldberG, D. E. and BArTon, A. M. 1992. Patterns and consequences of interspecific competition in natural communities - a review of field experiments with plants. Am. Nat. 139:771-801.

GuENTHER, A. 2002. The contribution of reactive carbon emissions from vegetation to the carbon balance of terrestrial ecosystems. Chemosphere 49:837-844.

Guenther, A., Hewitt, C. N., Erickson, D., Fall, R., Geron, C., Graedel, T., Harley, P., Klinger, L., Lerdau, M., Mckay, W. A., Pierce, T., Scholes, B., Steinbrecher, R., Tallamraju, R., Taylor, J., and Zimmerman, P. 1995. A global-model of natural volatile organic-compound emissions. $J$. Geophys. Res-Atmos. 100:8873-8892.

Harley, P. C., Litvak, M. E., Sharkey, T. D., and Monson, R. K. 1994. Isoprene emission from velvet bean leaves. Plant Physiol. 105:279-285.

Holopainen, J. K. 2004. Multiple functions of inducible plant volatiles. Trends Plant Sci. 9:529-533.

Kainulainen, P., Holopainen, J., Palomaki, V., and Holopainen, T. 1996. Effects of nitrogen fertilization on secondary chemistry and ectomycorrhizal state of Scots pine seedlings and on growth of grey pine aphid. J. Chem. Ecol. 22:617-636.

Larcheveque, M., Baldy, V., Korboulewsky, N., Ormeno, E., and Fernandez, C. 2005. Compost effect on bacterial and fungal colonization of kermes oak leaf litter in a terrestrial Mediterranean ecosystem. Appl. Soil Ecol. 30:79-89.

Litvak, M. E., Loreto, F., Harley, P. C., Sharkey, T. D., and Monson, R. K. 1996. The response of isoprene emission rate and photosynthetic rate to photon flux and nitrogen supply in aspen and white oak trees. Plant Cell Environ. 19:549-559.

Llusià, J. and Peñuelas, J. 2000. Seasonal patterns of terpene content and emission from seven Mediterranean woody species in field conditions. Am. J. Bot. 87:133-140.

Midoko-IpongA, D., Krug, C. B., and Milton, S. J. 2005. Competition and herbivory influence growth and survival of shrubs on old fields: implications for restoration of renosterveld shrubland. J. Veg. Sci. 16:685-692.

Millan, M., Salvador, R., Mantilla, E., and Artinano, B. 1996. Meteorology and photochemical air pollution in Southern Europe: experimental results from EC research projects. Atmos. Environ. 30:1909-1924.

Ninnemets, Ü., Seufert, G., Steinbrecher, R., and Tenhunen, J. D. 2002. A model coupling foliar monoterpene emissions to leaf photosynthetic characteristics in Mediterranean Quercus species. New Phytol. 153:257-275.

Orshan, G. 1989. Plant Pheno-morphological Studies in Mediterranean Type Ecosystems. Kluwer Academic, Boston.

PAssama, L. 1970. Composition minérale de diverses espèces calcicoles et calcifuges de la région méditerranéene française. Oecol. Plant. 5:225-246.

PEÑUElAS, J. and LluSi̇̀, J. 1998. Influence of intra- and inter-specific interference on terpene emission by Pinus halepensis and Quercus ilex seedlings. Biol. Plantarum 41:139-143.

QuÉzEL, P. 2000. Taxonomy and biogeography of Mediterranean pines (Pinus halepensis and P. brutia), pp. 1-12, in G. Ne'eman and L. Trabaud (eds.). Ecology, Biogeography and Management of Pinus halepensis and P. brutia Forest Ecosystems in the Mediterranean Basin. Backhuys, Leiden, The Netherlands. 
RAMSEIER, D. and WeINER, J. 2006. Competitive effect is a linear function of neighbour biomass in experimental populations of Kochia scoparia. J. Ecol. 94:305-309.

RoBles, C. 1998. Fonctionnement des cistaies à Cistus albidus L. et Cistus monspeliensis L. en Provence calcaire et siliceuse à travers la mesure des réactions écophysiologiques. Thèse de Doctorat en Sciences, biologie de populations et Ecologie, Faculté de Biologie, Université de Provence, Marseille.

Robles, C. and GarzinO, S. 1998. Essential oil composition of Cistus albidus leaves. Phytochemistry 48:1341-1345.

Simon, V., LuChetTA, L., and Torres, L. 2001. Estimating the emission of volatile organic compounds (VOC) from the French forest ecosystem. Atmos. Environ. 35:S115-S126.

Simon, V., Dumergues, L., Solignac, G., and Torres, L. 2005. Biogenic emissions from Pinus halepensis: a typical species of the Mediterranean area. Atmos. Environ. 74:37-48.

Staudt, M., Bertin, N., Frenzel, B., and Seufert, G. 2000. Seasonal variation in amount and composition of monoterpenes emitted by young Pinus pinea trees-Implications for emission modelling. J. Atmos. Chem. 33:77-99.

Tingey, D. T., Manning, M., Grothaus, L. C., and Burns, W. F. 1980. Influence of light and temperature on monoterpene emission rates from slash pine. Plant Physiol. 65:797-807.

VILA, M. and SARDANS, J. 1999. Plant competition in Mediterranean-type vegetation. J. Veg. Sci. 10:281-294. 